\title{
How Competitive is the Bangladesh's Apparel Export Firms? An Exploratory Content Analysis of the Unique Firm Resources Claimed by the Apparel Export Firms of Bangladesh
}

\author{
Ishtehar Sharif Swazan and Debanjan Das, West Virginia University, USA
}

Key words: Bangladesh, Content Analysis, Export, Firm Resources

Bangladesh has emerged as a powerful apparel manufacturing and exporting country in the world in the past decade. The apparel industry also plays a significant role and is a major contributor to the country's economy. Bangladesh exported USD 34.133 billion worth of apparel in 2018-19 and contributed $84.21 \%$ to the country's total export earnings in that period (BGMEA, 2019). Bangladesh is the $2^{\text {nd }}$ largest apparel manufacturer and exporter in the world (WTO, 2019). The apparel industry is also the biggest employment generator of Bangladesh. The significant contribution to the country's exports, employment generation and poverty reduction, has made this industry the most important sector for the socio-economic development of Bangladesh.

The government of Bangladesh facilitated the growth of apparel exports through setting up the Trading Corporation of Bangladesh to assist the apparel export companies by knowledge sharing (Yunus \& Yamagata, 2012). The government also implemented import tariff exemptions, free warehouse facilities and back-to-back letters of credit that helped the industry to grow (Alam, Selvanathan, \& Selvanathan, 2017). The Accord on Fire and Building Safety came into effect in 2013 to ensure better working condition for the worker and resulted in worker satisfaction that helped to increase apparel production rate (Accord, 2018). This was set up to address the working condition and occupational safety issues which has plagued the Bangladesh apparel manufacturing and exporting sector for years. Europe and USA are the largest apparel export partner of Bangladesh with exporting USD 20.58 billion and USD 5.844 billion in 2018 respectivly (BGMEA, 2019). Bangladesh's minimum wage in 2018 was USD 97 per month making Bangladesh an attractive option for the foreign buyers to source apparel (Paul, 2018).

Resource based theory of the firm states that a firm can achieve competitive advantages by implementing a value-creating strategy while other prospective competitors do not or cannot (Barney, 1991). Firm resources are defined as the tangible and intangible assets that firms use to develop and implement their strategies. In the export setting, researchers suggested that exporting firms require different firm resources for their competitive advantages, compared to general firms. In this light, firm resources, such as financial, physical, human, organizational knowledge and learning, and general organizational, are key for firms' competitive advantages in an export setting (Enz, 2008). Previous research on Chinese textile and apparel firms revealed that good relationships, customer satisfaction, reputation, location, financial resources, awards, and industry certificates are key resources for their competitive advantages (Chang \& HaBrookshire, 2011). Previous research on Indian apparel export firms revealed that quality,

Page 1 of 4

(c) 2020 The author(s). Published under a Creative Commons Attribution License

(https://creativecommons.org/licenses/by/4.0/), which permits unrestricted use, distribution, and reproduction in any medium, provided the original work is properly cited.

ITAA Proceedings, \#77 - https://itaaonline.org 
experience, infrastructure, location, skillful workforce, and timely delivery are key resources for their competitive advantages (Das \& Ha-Brookshire, 2013). With regards to Bangladesh apparel export firm, some insights into the Bangladesh's key resources are available (Yunus \& Yamagata, 2012). However, little research is available on the individual firm resources in the Bangladesh apparel sector. To fill this gap, the study was designed to explore the type of firm resources that Bangladesh apparel exporters claim to have. A content analysis was used to analyze the firm resources reported by the apparel manufacturers and exporters of Bangladesh. Web-based communication data was used in this study to analyze the main themes of the firms. The text data under "About Us", "Company Information", "Who We Are", "Know Us", "What We Do" available on each firm's web site were reviewed and coded.

Sample firms in this study were selected from the directory of apparel manufacturers and exporters published by Bangladesh Garment Manufacturer and Exporter Association (BGMEA) in 2020. A total of 4,357 garment manufacturing firms registered under the BGMEA were analyzed and only 672 firms were found to have their proper websites. 328 firms were randomly selected of these 672 firms using the random number generating scheme available through www.random.org (Haahr, 2019). The text data was coded and interpreted for reoccurring themes, according to the Enz's (2008) key firm resource framework.

The results of content analysis revealed 23 unique key resources that were claimed by the apparel manufacturing and exporting firms in Bangladesh. They were (1) quality [277 out of 328 or $84.5 \%$ ], (2) on time delivery [169 out of 328 or 51.5\%], (3) Management [202 out of 328 or $61.6 \%$ ], (4) product breadth [181 out of 328 or 55.1\%], (5) competitive price [103 out of 328 or $31.4 \%$ ], (6) customer satisfaction [214 out of 328 or $65.2 \%$ ], (7) design [48 out of 328 or $14.6 \%$ ], (8) fashion trend [25 out of 328 or $7.6 \%$ ], (9) infrastructure [180 out of 328 or 54.9\%], (10) location [299 out of 328 or $91.1 \%$ ], (11) apparel production equipment [129 out of 328 or $39.3 \%$ ], (12) textile equipment [ 68 out of 328 or $20.7 \%$ ], (13) size [205 out of 328 or $62.5 \%$ ], (14) domestic operations [6 out of 328 or $1.8 \%$ ], (15) experience [254 out of 328 or $77.4 \%$ ], (16) good relation to buyer [181 out of 328 or $55.1 \%$ ], (17) reputation [214 out of 328 or $65.2 \%$ ], (18) award [35 out of 328 or $10.7 \%$ ], (19) skilled employees [137 out of 328 or $41.8 \%$ ], (20) designers [18 out of 328 or 5.5\%], (21) relation to workers [205 out of 328 or $62.5 \%$ ], (22) training programs [ 27 out of 328 or $8.2 \%$ ], and (23) finance [ 76 out of 328 or $23.1 \%$ ]. A total of 3253 key resources were coded throughout the study sample, resulting in 9.9 resources described by each firm.

These 23 key firm resources were then classified into five unique themes / categories following Enz (2008) firm resource framework. First quality, on time delivery, management, product breadth, competitive price, customer satisfaction, design, fashion trends were categorized into organizational knowledge and learning resources and 1,219 occurrences were found in this category, resulting in an average of 3.72 resources per firm. Second, infrastructure, location, apparel production equipment, company size, textile equipment's were categorized into physical

Page 2 of 4

(c) 2020 The author(s). Published under a Creative Commons Attribution License

(https://creativecommons.org/licenses/by/4.0/), which permits unrestricted use, distribution, and reproduction in any medium, provided the original work is properly cited.

ITAA Proceedings, \#77 - https://itaaonline.org 
resources with a total of 887 occurrences averaging 2.70 resources per firm. Third, experience, good relation to buyer, reputation and awards were classified into general organizational resources with a total of 684 occurrences averaging 2.08 resources per firm. Fourth, designers, skilled employees, relation to workers and training programs were classified into human resources with a total of 387 occurrences averaging 1.18 resources per firm. Finally, all types of financial information and annual turnovers were classified into financial resources with a total of 76 occurrences averaging .23 resources per firm.

The study findings have important implications and contributions. The study presents the valuecreating strategies claimed by the Bangladeshi apparel export firms demonstrating the unique firm resources that are important for the success of Bangladesh's apparel export industry. The study result showed that quality is considered as the most important resource by the apparel exporting firms in Bangladesh followed by on time delivery and customer satisfaction. Interestingly, financial resource was the least reported resource by the Bangladeshi apparel export firms. Examining the firm resources of Bangladesh allows sourcing personnel, foreign buyers, owners and government policymakers to better understand the resources affecting the ever-changing apparel field. Future research is recommended to investigate the reason for such least occurrence in human and financial resources the apparel export firms of Bangladesh.

References

Accord. (2018). Retrieved March 18, 2020, from Safe Workplaces: https://bangladeshaccord.org/

Alam, M., Selvanathan, E., \& Selvanathan, S. (2017). Determinants of the Bangladesh garment exports in the post-MFA environment. Journal of the Asia pacific Economy, 22(2), 330352. Retrieved September 28, 2019, from https://doi.org/10.1080/13547860.2017.1292768

Barney, J. (1991). Firm resources and sustained competitive advantage. Journal of management, 17(1), 99-120.

BGMEA. (2019). Retrieved March 15, 2020, from Bangladesh Garment Manufacturers and Exporters Association: http://www.bgmea.com.bd/

Chang, T.T., \& Ha-Brookshire, J. (2011). Business activities, competitive resources and ownership types of Chinese textile and apparel manufacturing firms. International Journal of Fashion Design, Technology and Education, 4(2), 115-125.

Das, D., \& Ha-Brookshire, J. (2014). India, the next China? Analysis of the unique firm resources claimed by Indian apparel export firms. Journal of Fashion Marketing and Management, 18(4), 378-393.

Page 3 of 4

(c) 2020 The author(s). Published under a Creative Commons Attribution License (https://creativecommons.org/licenses/by/4.0/), which permits unrestricted use, distribution, and reproduction in any medium, provided the original work is properly cited.

ITAA Proceedings, \#77 - https://itaaonline.org 
Enz, C. A. (2008). Creating a Competitive Advantage by Building Resource Capability:The case of Outback Steakhouse Korea. Cornell Hospitality Quarterly, 49(1), 73-78.

Haahr, M. (2019). Random.org. Retrieved December 16, 2019, from https://www.random.org/

Paul, R. (2018, September 13). Bangladesh raises wages for garment workers. Retrieved March 25, 2020, from Reuters.com: https://www.reuters.com/article/us-bangladeshgarments/bangladesh-raises-wages-for-garment-workers-idUSKCN1LT2UR

WTO. (2019). World Trade Statistical Review. Retrieved March 6, 2020, from World Trade Organization: https://www.wto.org/english/res_e/statis_e/wts2019_e/wts2019_e.pdf

Yunus, M., \& Yamagata, T. (2012). The Garment Industry in Bangladesh. Dynamics of the Garment Industry in Low Income Countries: Experience of Asia and Africa, chapter 6. Retrieved September 28, 2019, from https://pdfs.semanticscholar.org/e77b/bea34abdf7d935a2439d4ff031cd73f8dcf3.pdf 